\title{
The Peaceful Settlement of Syrian Refugees in the Eastern suburbs of Beirut: Understanding the causes of social stability
}

Marianne Madoré

\begin{abstract}
Since early 2011, the few episodes of violence involving refugees in Lebanon have been covered extensively. Yet, given the high numbers of displaced people, the proximity of the battles, and the preexisting pressures in Lebanon, one could have expected many more clashes to take place. This article focuses on the densely populated municipality of Bourj Hammoud, where the proportion of registered Syrian refugees has reached a fifth of the local population without leading to any major violent episodes. Based on extensive ethnographic study, this article explains the social stability that prevailed by highlighting mechanisms of regulation and control, the management of the influx of refugees by local actors, and the agency of the refugees themselves in the settlement process.
\end{abstract}

Keywords: Syrian Refugees, Borj Hammoud, Peace \& Security

To cite this paper: Marianne Madoré, "The Peaceful Settlement of Syrian Refugees in the Eastern suburbs of Beirut: Understanding the causes of social stability ", Civil Society Knowledge Center, Lebanon Support, March, 2016 . DOI: 10.28943/CSKC.001.40001.

[ONLINE]:

https://civilsociety-centre.org/paper/peaceful-settlement-syrian-refugees-eastern-suburbs-beirutunderstanding-causes-social

\section{Introduction 1}

The sky is clear and the rain has finally stopped. It feels like a short interruption in a long week of damaging storms. In 2015, Lebanese meteorologists named each storm that hit the country "Zena" if it came in January, "Jina" in early February and "Johan" in late February. Naming these storms made them sound extraordinary and attracted the attention of the media. Between the passing of two of these storms, an unnoticeable scene between Syrian refugees who remain nameless in the media took place in front of a school in Bourj Hammoud. Mothers, fathers and aunts were waiting for their children. Samer $\underline{2}$, the doorman, opened the school's doors at noon, and children ranging from the age of 11 to the age of 15 flooded the schoolyard. Suddenly, loud yelling booms through the yard: a boy having an argument with a fellow schoolgirl shouts with annoyance. The girl shouts back. The parents quickly intervene as Samer asks everyone to calm down. Two minutes later, the episode is over. This is ordinary life in the streets of Bourj Hammoud. Parents go back to their conversation about the storms and the Syrian refugees remain in the background. The settlement of the refugees in Bourj Hammoud suburbs is also a succession of everyday mundane interactions, away from the extraordinary figures and the frightening stories associated with the Syrian crisis.

Since the beginning of 2011 , it is estimated that 1.5 million Syrian de facto-refugees are in the country. 
$\underline{3}$ Before the crisis, Lebanon had a population of 4.4 million, which makes the ratio of refugees per inhabitant currently the highest on the planet: "The extent of the burden of the Syrian crisis has fallen more acutely on host communities in Lebanon than in any other country." 4 If for decades political analysts have endlessly argued that Lebanon was on the edge of civil war, $\underline{5}$ the Syrian conflict has undeniably increased the possibility of strife. Combined, the memories of the 15-year long Lebanese civil war, the lasting presence of militias, the easy access to weapons, and the ongoing sectarian tensions, along with the endemic weakness of the Lebanese state, accentuate this threat. Furthermore, due to the geographical and political proximity of the Syrian battles to Lebanon, the crisis is particularly prone to cause insecurity and instability. $\underline{6}$ and has revived anger against the Syrian army, which occupied the Lebanese territory for three decades (1976-2005). In fact, a nation-wide survey showed that the refugees in Lebanon were perceived as a main security threat for the country. $\underline{7}$ Notably, records of massive refugee flights across many continents often reveal links to the growth of criminal networks and the rise of insecurity within the host country.

The arrival of thousands of Syrian refugees has undeniably led to conflicts across Lebanon. Local and international newspapers have extensively covered the few episodes of violence involving refugees. $\underline{9}$ Non-Governmental Organizations (NGOs) and United Nations (UN) agencies have produced countless reports on the tensions between refugees and "host communities." 10 In this context, the noteworthy peacefulness and the lack of unrest and clashes in the metropolitan area of Beirut caught my attention. The large metropolitan area of Beirut, a city marked by decades of armed conflicts and militarized frontlines 11 now hosts close to 300,000 Syrian refugees.12 This article explores why, despite its apparent threat to social stability in Lebanon, Syrian refugees' arrival in the metropolitan area of Beirut has not led to any major uprising or turmoil.

\section{Theoretical framework: Why Bourj Hammoud?}

Over the last few decades, the reconstruction of Beirut was driven by neoliberal real-estate developers willing to attract foreign capital.13 The sanitized spaces of the inner city, fitting norms of security and well-being, 14 were not designed to host the urban poor. Thus, most of the refugees settled in the suburban quarters 15 where they improvised housing facilities (basements, garages etc.). 16 Bourj Hammoud, a few square kilometres large, located in the immediate Eastern suburbs of Beirut, is an appropriate area to study the settlement of Syrian refugees, as it has hosted close to 20,000 refugees since $2011 . \underline{17}$

The locality had 100,000 residents prior to the crisis, which makes the current ratio of refugees compared to the local population one out of five - the highest in the metropolitan area of Beirut according to the latest cadastral breakdown released by the United Nations High Commissioner for Refugees (UNHCR).18 The numbers are higher according to local officials who noted that approximately 34,000 Syrians refugees live in Bourj Hammoud, amounting to a total population of nearly 150,000 people to administer to: "Out of those 34,000 Syrians, we don't know how many work here exactly right now. But the bottom line is that you have a huge, a huge population to administer." 19 In fact, in some of the streets, half of the residents are now Syrian refugees.

Bourj Hammoud is an attractive settlement destination for Syrian refugees because it combines potential job opportunities in factories, garages or nearby construction sites with affordable and rentable 
commodities. For decades, the locality has hosted poor workers from North and East Africa, Egypt, Iraq, and South-East Asia. Even in the 1970s, it was described as the most heterogeneous district in Lebanon.20 In the street cafés under the Yerevan Bridge, the shisha costs 3,000 LBP as opposed to the average 10,000 LBP in Beirut. A few blocks further, the take-away espresso costs 750 LBP whereas the standard price in inner Beirut is 1,000 LBP. Among the 225 localities identified by the UNHCR in Lebanon as vulnerable, 21 the municipality of Bourj Hammoud is classified as the "most vulnerable" because more than half of its Syrian and Lebanese inhabitants are living under conditions of financial distress. These alarming living conditions have been successively highlighted by international organisations, 22 which have also underlined the unpreparedness of the municipal agents and their lack of financial resources.

On 18 May 2014, an argument between two groups of young men in Bourj Hammoud ended with one of the men throwing a gas bottle from the second floor of a residential building, which hit a passer-by in the street below. The event was extensively covered by the Lebanese and international media23 and Bourj Hammoud was in the highlights for a couple of days. Despite this, the news outlets rarely covered Bourj Hammoud after, when everything went back to normal. The episode remained a rather isolated event. Arguments and disputes take place every day in Bourj Hammoud, but they revolve around minor issues between neighbours or parking arguments. Hassan, a Syrian who arrived in Bourj Hammoud two years ago, comments:

“I don't know the specifics. Small fights... I don't know the specific problems, but there are disagreements. When your business is good, as the owner of a café, if a customer comes and he sits for three hours for one espresso, you don't mind... because business is good. But when the days are rough and money is starting to lack, you tell him, 'Go or order another coffee." 24

Yet, remarkably, these types of perturbations do not lead to episodes of large-scale violence in Bourj Hammoud. What seems to prevail is a general feeling of security among the residents and the refugees. How may one explain this curious non-violence?

My research was guided by a classic concern of the school of grounded ethnography. As stated by $\mathrm{E}$. Goffman in his study of the role of public spaces in 1963, "It is well recognized for instance, that mobs can suddenly emerge from the peaceful flow of human traffic [...] But little concern seems to have been given to the question of what structure this peaceful intercourse possesses when mob formation is not an issue." 25 This article does not look at riots and panics, but is concerned with the remaining part of collective behaviour: "The study of ordinary human traffic and the patterning of ordinary social contacts," 26 when there is no mobilization and crowds. The aim is to understand the inner-workings of social order and of the "peaceful flow of human traffic." Nonetheless, from an academic standpoint, I distanced myself from the school of grounded ethnography, as I did not intend to develop new sociological theories based on the observation of a local case study. Instead, this thesis considers Bourj Hammoud as an anomaly in the existing body of literature on migration, which tends to picture refugees as perturbations and focus on the exceptional features associated with their influx.27 I studied the Eastern suburbs of Beirut not willing to extend the findings to the whole country or coin new 
concepts, $\underline{28}$ but with the ambition that mechanisms identified in these suburbs would contribute to a more sophisticated understanding of the settlement patterns and urban poverty realities in Lebanon. Thus, this article also builds on the inputs of urban studies on public spaces and civility in cosmopolitan settings. 29 It is based mostly on qualitative data collected during months of field observation, volunteering in local organizations and interviews with long-term residents, refugees, community leaders, social workers, police, and municipal officers and staff from international organizations.

Five years after the beginning of the Syrian crisis, this article suggests a threefold explanation to the ordinary human traffic in Bourj Hammoud.

\section{The efficient handling of the inflow by civil society in Bourj Hammoud}

There can be no recipe for harmony and peacefulness. This section goes beyond the orientalist explanation pointing at the legendary Lebanese hospitality, $\underline{30}$ and rather underlines the role of a specific local history combined with the shortfalls of the international community.

\subsection{A long history of welcoming: hospitable residents and dynamic local organizations}

When the first Syrian refugees arrived in Bourj Hammoud, the various residents and local organizations reactivated longstanding welcoming practices specific to Bourj Hammoud. At the beginning of the 20th century, Beirut's population was less than 100,000. On its eastern edge, there were swampy farmlands of sugar cane and silkworm trees. During the following decades, the urban transformation of those lands took place according to the nearby international crises. The first waves of Armenian and Syrian refugees, fleeing the massacres by the Ottomans arrived in 1921. They established the municipality of Bourj Hammoud. In 1933, a fire destroyed the other district that the Armenian refugees had occupied, the camp of Qarantina in the North of Beirut, which was hosting close to 10,000 refugees.31 Consequently, more Armenians moved to Bourj Hammoud. After World War II, the Soviet Union attracted many of them, who went "back" to Soviet Armenia leaving their houses empty. They were not vacant for long, however, the creation of Israel in 1948 and the eviction of Palestinians brought new refugees to Bourj Hammoud. After Lebanon's independence, in 1943, the cultural and business elites from neighbouring Arab countries were attracted to the booming inner-Beirut region, while, low-income refugees resided in the suburbs. The 1956 Arab-Israeli war forced the Southern Shi'a Lebanese living close to the war zone to flee, causing many to settle in Bourj Hammoud. In the 1960s and 1970s, the Syrians, Egyptians and Iraqis, running away from political and economic uncertainties were again hosted in Bourj Hammoud. The 1967 and 1973 Arab-Israeli wars further brought new Lebanese Southerners to the area. Bourj Hammoud became Lebanon's third largest urban centre, a "warehouse of refugees and a waystation for poor members of practically every sect of the fertile crescent." 32 The Israeli invasions (1978 \& 1982) and the occupation of South Lebanon (1978-2000) continued to push the Southern Lebanese out of their homes. Since the 1990s, foreigners from the Philippines, Sri-Lanka, Bangladesh, India, Ethiopia, Somalia, Ghana, and Sudan also moved there, along with other ethnic groups such as the Kurds. 33 These migrants have made Bourj Hammoud a diverse and dynamic commercial area, and thus, an area where newcomers can settle in quite easily. The shops selling international telecommunications plans are now even offering cheap calls to Syria and Turkey: 3 minutes for 1,000 LBP. 
Varouj, an Armenian shop-keeper and long-term resident of Bourj Hammoud insists: "We, as well, we were refugees!" 34 He lives in his mother's apartment in the neighbourhood of Nor-Marash, named after the city of Marash in Armenia. When the first refugees from the Syrian war started to arrive during the summer of 2011, some residents adopted the role of hosts, as they could relate to the desperate situation of the newcomers. Some opened their houses for free; sometimes because they had ties with the refugees which pre-dated the crisis, and sometimes out of a sense of moral obligation. Some remembered the 2006 war against Israel when the Lebanese had been forced to find shelter in Syria and therefore they wanted to give back. Hafez, a resident of Bourj Hammoud working as a social worker, insisted that the situation was not extraordinary, but rather familiar:

"We had the same experience when there were clashes with Israel in the South in 2006 and around 50,000 refugees left their home from the South and came to Beirut and the suburbs. So we had the same experience before." 35

The residents organized donation campaigns of clothes and furniture for the refugees. During the Lebanese civil war (1975-1990), Bourj Hammoud, in the Eastern part of the city, was located in the Christian camp. Yet, it was seen as a relatively safe haven, since the Armenians had taken a neutral stance between the divisions of the Christian and the Muslim communities. Often, local residents recall the episodes of the Armenians helping the Sunni Palestinians or the Shi'a Lebanese to reach the other side of the city safely:36 "The only place where there was no massacre was Bourj Hammoud! It was surrounded by militias, so the Armenians escorted, under their protection, the Muslims to West Beirut." 37 This anecdote, no matter if it is historically accurate or not, is part of the construction of Bourj Hammoud as a shelter within a city marked by conflict. Whether fantasized or real, this neutrality played a role in the acceptance of refugees.

In addition, local communities were not reluctant to endorse the role of host as they were able to benefit from it on an individual level. Refugees were seen as potential renters, cheap workers and customers. A multitude of small grocery stores decided to extend their activities and purchased espresso machines. They added half a dozen of plastic chairs on the sidewalks and started selling coffees for 500 LBP. The local communities were also keen on hiring cheap labour forces: fruit and vegetables shops, as well as garages, hired Syrian workers. Beyond the raw profits, hosting refugees also tied the local residents to the newcomers, as Sophia, a long-time Armenian resident recalled:

"It is not only forced cohabitation, it is like interaction. We work together. It is not friendship. I am not talking about mixed marriages. But I am talking respect. I hear many foreigners say that they learn their jobs from Bourj Hammoud. That they learn from the Armenians." 38

Local associations also played a key role in welcoming refugees. Bourj Hammoud, predominantly populated by low-income residents, hosts a dense network of neighbourhood associations, community 
centres, dispensaries, churches, religious centres, and children clubs. These associations have been working on the issues of unemployment, school dropouts, child labour, prostitution, and drug-addiction for years. With their experience, efficient coordination, and reliance on faithful and rooted workers they effectively catered for the needs of the newcomers. At the very beginning, the local associations willingly extended their existing programs to the new refugees. A few years into the crisis, they started developing a new formula to meet the extraordinary needs.

The association of Dar al-Amal (The House of Hope), one of the very active associations that informants kept mentioning, is located on the first floor of a red three-story building located in the very heart of the dense neighbourhood of Naba'a, Southern Bourj Hammoud. As I had lost my way, I asked someone for directions: "Oh yes, Dar al-Amal easy, everyone knows them... keep going straight and then first right!" The walls in the main room of the NGO are covered with children's drawings. Noha, one of the two social workers at Dar al-Amal, explains: "We have always done a lot of recreational activities and handicraft, games, songs... So we integrated the Syrian kids in that." The rather small NGO, which employs 10 people, demonstrated impressive reactivity by also thinking about the specific needs of the Syrian refugees and set up ad-hoc programs. Like Noha, most of the staff of local organizations in Bourj Hammoud are long-time residents, devoted to their occupation, who consented to double their workload since 2011 in order to cope with the needs on the ground. They were also supported in their tasks by the local municipalities that, unlike other municipalities, were rather welcoming to the refugees.

"His openness is remarkable... [The vice-mayor] really has vision for the community: ideas, projects. He is motivated." Harry, British country officer of an international NGO active in Lebanon, 39 describes the unusual stance taken by the municipality of Bourj Hammoud on the crisis. Certainly, the vice-mayor of Bourj Hammoud is very critical of the current official response to the crisis in which "everyone speaks about [refugees], begs money for them... but at the end of the day, nothing reaches the refugees except peanuts." 40 Quickly after the arrival of the refugees, the municipality provided extra trucks to the company Sukleen and showed lenience towards the informal collection system that started operating in some neighbourhoods. Above all, the municipality played the role of facilitator between newcomers and local associations. At the beginning of 2012, a few municipal agents registered refugee families coming to the town hall and filled out four large papers with their names and precise needs. At the same time, the municipality improved its support to local NGOs and encouraged their cooperation.

\subsection{A convenient target for unprepared humanitarian actors}

Prior to the crisis, the unconventional characteristics of the area - low socio-economic status, high density, and high percentage of migrants - had attracted world-class stakeholders such as the World Bank and UN-Habitat.41 Consequently, at the beginning of the Syrian crisis, the municipality of Bourj Hammoud was coloured in "priority" red on the UNHCR maps, 42 emphasizing the concentration of refugees and thus attracting international donors who follow the UNHCR's recommendations. 43 The attractive developmental characteristics of Bourj Hammoud were reinforced in April 2013 with the introduction of the Regional Response Plan (RRP5) and its concern for the so-called "host communities" and the need for "social cohesion." 44 Bourj Hammoud was then coloured in a deeper shade of red. 45 This led to the launch of a few projects on "conflict prevention" in the area. As so, humanitarian actors rehabilitated houses and distributed blankets, mattresses, hygiene items, and cash 
to refugees as well as long-term residents of Bourj Hammoud.

The numerous shortcomings of the international humanitarian response to the refugee crises are well known in Lebanon and include the lack of coordination between global actors and the high turnover of staff in international organisations.46 In Bourj Hammoud, like elsewhere, approximations tainted humanitarian interventions. Especially during the first years of the crisis, international actors implemented many blanket projects with scarce attention to local needs. 47 However, in Bourj Hammoud, the implementation of humanitarian initiatives benefited from the precious help of the municipality and of local organisations. I asked the deputy director of a leading French NGO how they implemented their house rehabilitation program in Bourj Hammoud. His answer was straightforward: "Having someone from the municipality to help us, someone who is motivated for this sort of thing really makes the difference." $\underline{8}$ Since 2011, a few individuals have contributed in bridging the distance between foreign NGOs and the reality of Bourj Hammoud. These individuals are employees of the municipality, but also members of local churches, political parties, youth clubs, and other socially active groups within the Bourj Hammoud community. They have operated as informal "link workers", able to understand the expectations and standards of the international NGOs and provide them with advice and legitimacy on the field. For instance, Therese, who runs an association for street children and has been living in Bourj Hammoud for years, has played the role of "guide" for international NGOs not familiar with the area. Similarly, Father Alberto, a local Italian priest, convinced foreign donors to support local needs thanks to his knowledge of the area. There is also, Serop, the dynamic director of the Karagheusian health care centre. He has learned over the last few years how to respond to calls for tender, as well as how to write calls for funding. In the stairs that lead to his office, a small Japanese flag is framed under a plaque that is inscribed with the words: "Equipping the primary health care centre to support Syrian Refugees and the Host Communities - Bourj Hammoud - 31st of October 2014 - Japan - Grant Assistance for Grassroots Project". In his office on the paperboard, there is a list of deadlines and acronyms underlined like "UNDP" and "UNHCR". Serop has crafted "a memorandum of understanding" with the UNHCR that states that the UN agency will cover $75 \%$ of the costs of medical services provided to Syrian refugees. Any Syrian benefiting from a medical consultation at the Karagheusian centre now pays 2 USD, the remaining 6 USD are covered by the UN.

Thus, "link-workers" helped in reducing the gap between international jargon and local reality when the first refugees arrived. These individuals have various nationalities, some being Lebanese, Armenian or Syrian, while others come from European or North-American origin. Because they are familiar with local needs and often affiliated with a political party, $\underline{49}$ they were able to offer advice and legitimacy to international aid-providers. When I asked Kevork what his job entailed at a refugee centre that an international NGO opened in Bourj Hammoud in 2015, he was unable to give a clear answer; "Technically, I am the contact person if something happens with the school, with everything...Technically that is me. Plus I go to... I am in charge of the..." 50 Even if the title of his position is unclear, Kevork's actions were crucial to the integration of the centre in the neighbourhood. Last summer, the centre had trouble with the neighbours because of the loud noise children were making in the courtyard. The neighbours complained and threatened to call the municipality and the police. Kevork, who is Armenian and grew up in Bourj Hammoud, spent long diplomatic hours negotiating with the neighbours and begging for their patience. As part of this, he invited the neighbours' children to take part in the recreational activities of the centre. 


\section{3. ... yet, Bourj Hammoud is no refugee heaven}

With the Syrian refugee crises, and taking into account the lack of resources to support these refugees in the area, the framing of Bourj Hammoud as a priority for international aid, combined with the dense and dynamic social fabric of the locality, enabled the peaceful settlement of refugees and allowed for their relatively easy social cohesion. Yet, one should not portray Bourj Hammoud as heaven for Syrian refugees. Decades of war and political tension between Lebanon and Syria have translated into racism and the scapegoating of the weakest. Newspapers and popular sayings have conveyed the image of "the Syrian refugee" as uneducated, helpless, and aggressive. 51 On the 6th of January 2015, the Lebanese newspaper An-nahar published an opinion piece criticizing the Syrian presence in the downtown public spaces. 52 The author accused Syrians of depriving the emblematic Hamra Street from its identity: "The demographics have changed; the Syrians are taking over the landscape and pushing away the Lebanese." The long-term presence of Syrian workers combined with the deep involvement of the Assad regime in local politics has led to the fear among many Lebanese of the Syrianisation of their country's economy and culture. $\underline{53}$

In Bourj Hammoud, as elsewhere, Syrian refugees are seen as an undesirable public. There are countless episodes of ordinary discrimination in various contexts. A taxi driver does not stop to pick up the Syrian worker waving at him. The manager of the restaurant yells at the Syrian waiter for no apparent reason. One Tuesday afternoon in March 2014, I entered a tiny printing shop on Bechara Khoury Street, which was full of customers. The two owners of the shop were looking for an additional person to help them. I told them that a friend, Alaa, was looking for a job. They asked: "He is Syrian? We don't like Syrians [...] in the daytime they are nice and quiet. But at night they kill, they steal, they murder, you cannot trust them." They said this quietly but everyone in the shop heard their remarks and no one reacted. Later, I asked him if he had personally experienced this. He told me the story of a priest driving on the way to the church and who gave a ride to a Syrian worker. The Syrian worker ended up "stabbing the priest and stealing all his money." While loading the printer with white papers, he mimicked the act of stabbing: "We don't want a Syrian employee here." The veracity of this bloody episode can hardly be verified but the strength of the accompanying prejudice has undeniable consequences on the everyday interactions between Syrians and Lebanese.

Thus, the prompt welcome of Syrian refugees by residents and local organizations of Bourj Hammoud does not make the locality a dreamland for refugees. The long history of Syrian military occupation in Lebanon and labour migration has contributed to the manufacture of the villainised "Syrian refugee," a figure easily used by others to escape responsibility and blame. In this context, the peaceful settlement of Syrian refugees in Bourj Hammoud requires further explanation. The next section attempts to break down the misleading stereotype of "the Syrian refugee" in order to refine our understanding of the settlement patterns in Bourj Hammoud.

\section{Who is the undesirable refugee and do "host communities" only host? Local strategies of regulation and control}

In order to explain the non-violence that prevailed in Bourj Hammoud, the category of "the Syrian refugee" needs to be broken down into a complex multiplicity of identities and stories. Refugees were not integrated as a whole in the social fabric of Bourj Hammoud. Instead, the mechanisms of welcoming 
were applied unevenly to newcomers, following communitarian or political affiliations.

\subsection{The selective "hosting" of the locals (Armenian Lebanese hosting Armenian Syrian)}

Syrian refugees, though categorised by media and the Lebanese population as generally uniform in personality and background, are a heterogeneous group. Refugees may be young students in Business and Administration from Damascus, middle-aged low-income workers from Homs, pregnant revolutionary teachers, Sunnis, Alawis, Christian Orthodox, or residents of the infamous suburbs of Aleppo, or Erbil. It is hard to estimate precisely the sectarian, religious and geographic composition of the population of Syrians in Bourj Hammoud. The registration data of UNHCR combined with the information given by the refugees themselves show that more than half of the Syrian refugees in Bourj Hammoud are Kurdish Syrians. The majority of them are from Aleppo and a minority comes from Qamishli, Erbil, and Damascus. The rest are Sunni Syrians and Armenian Syrians, mostly from Aleppo and Erbil. In this context, the popular image of the indigent refugee must be assessed. Undeniably, the Syrians living in Bourj Hammoud are among the poorest dwellers within the municipality. However, these Syrians, who managed to reach the suburbs of Beirut and are able to pay rent in Bourj Hammoud, are better-off than the refugees who stay in the North of Lebanon or in the Bekaa region, along the border.

The geographical origin or sectarian affiliations of these Syrians are crucial variables in their settlement in Bourj Hammoud. Previous academic studies of Bourj Hammoud has pointed out that each ethnic and religious community relies on its own network for support. 54 Even though Bourj Hammoud is a cosmopolitan area, distinct communities have their own specific spaces - community centres, political parties or churches - to gather. These divisions translate into spatial grouping in the city: "See this woman? If she turns right she is Syrian Shi'a, and if she turns left she is probably not!" says a resident of Bourj Hammoud, on the main street under Yerevan Bridge. Each neighbourhood or street is associated with a population group: Marash and the Northeastern districts are Christian Armenian; Naba'a is Shi'a; Dora is very heterogeneous with many East African and Asian communities, etc. When the Syrians arrived in Bourj Hammoud, each community took care of "its" own refugees.

Since the early 1990s, young Syrians from Azzaz and Afrin (in the suburbs of Aleppo) were employed as seasonal workers in the numerous factories of Bourj Hammoud. $\underline{55}$ At the beginning of the war in Syria, they welcomed their families and friends. These previous connections offset the image of random waves of arrivals. It also contributes to explain the relative peacefulness of the process. Residents and social workers underlined the fact that the arrival of these male workers' wives and young children had a positive impact on the overall security in the neighbourhood. In many buildings, family life has replaced the old tensions that used to take place between the residents and the young male workers as expressed by Noha, a social worker in Naba'a:

"Before the Lebanese families were complaining because of the young Kurdish workers in their building, like 10 workers in the same flat. It was creating problems, you know. But now there are families. It is not men alone anymore. So it is a bit different." $\underline{6}$ 
The communitarian and religious affiliations also played a role among local Lebanese residents. Through the Syrian crisis, many Armenian Lebanese saw the opportunity to revive the Armenian identity of Bourj Hammoud and maintain its influence within the municipality. When the first Syrian Armenians arrived from Syria after 2011, the local Armenian institutions mobilized extra-resources and energy to support them specifically, for example, in primary health centers and in schools.

"We are very happy because all the Armenian Syrian are moving to Bourj Hammoud. We created this new place, [the municipality of Bourj Hammoud] you know. We want to keep it for the Armenians." $\underline{57}$

"The political parties are trying super hard to keep that main part [...] Arax and Marash Street and all the way to Mesropian School and the bridge." $\underline{58}$

The Tashnak, the party dominating the political scene in Burj-Hammoud, $\underline{59}$ prevents the real-estate owners to sell their property to non-Armenians. Thus, the arrival of Syrian Armenian refugees has been the opportunity for nationalists to strengthen the Armenian community. The local political clubs have opened their doors to refugees. The Lebanese government, by "outsourcing" the provision of vital services (health, education and housing) to the private sector and not offering public alternatives, has encouraged this trend. The sectarian identity of the refugees therefore becomes a tool to resolve daily needs and problems. The instrumentalisation of sectarian affiliations is not new to Bourj Hammoud. 60 The present inflow of refugees shows that sectarian identity remains a tool that refugees and host community can mobilise.

In the case of Bourj Hammoud, the politicisation of the crisis helped the refugees who fit into a specific political party to attract services and goods. There is no such thing as one host community but rather a variety of interests and strategies towards refugees. The microcosm of Bourj Hammoud is structured by "a macrocosm that assigns it its place and implies a dense web of social relations beyond the local site." 61 The multiplicity of identities and sectarian affiliations has, in turn, triggered differentiated support from locals over the last four years.

\subsection{Discontinuous control: the flexible enforcement of curfews}

The hospitality of local residents in Bourj Hammoud only accounts for part of the response to the arrival of refugees. 62 In July 2014, the municipality of Bourj Hammoud, following 53 other localities in Lebanon, imposed a curfew on Syrian refugees. 63 In Arabic, the word for curfew mana'a et-tajawel literally translates into "interdiction of wandering." The objective is explicit: banning the undesirable from public spaces. It restricts the right to be present in open, un-walled public spaces as the mere presence of a Syrian refugee becomes an "improper act." 64 For instance, in the municipality of Sin el-Fil, located in the Eastern suburbs, immediately south of Bourj Hammoud, the mayor set-up a strict system targeting the illegal Syrian workers.

"[The mayor of Sin el-Fil] has started a system that the people from Syria... not the residents... 
but the workers from Syria... them... directly we arrest them! I mean directly, directly! We grab them, we catch them. Maybe we warn them the first time. [...] The mayor says that they are threat or danger. Me, I don't know, in my opinion I don't know. But [...] the ones who are coming up here. Sometimes they steal, they beat, they disrupt, they damage. So we have to control the situation." $\underline{65}$

In the municipality of Sin el-Fil, one can see a policeman every four or five blocks at night. However, a few kilometres away in the locality of Bourj Hammoud, policing of streets differs. In Bourj Hammoud, the implementation of the curfew is flexible and discontinuous. This flexibility in enforcing the curfew is another component of the social stability that has prevailed in Bourj Hammoud.

In July 2014, the municipality of Bourj Hammoud announced the implementation of a curfew on Syrian refugees. From $7 \mathrm{pm}$ to $7 \mathrm{am}$, for the duration of a few weeks, Syrians would not be able to be in the streets. The Syrian refugees were warned by large ads hung outside. The installation of the curfew was triggered by an altercation between a group of refugees and a group of residents in June 2014. By suddenly banning the access to public spaces to a specific population, the curfew was, and still is in other areas, a segregationist practice against humanitarian law, but the vice-mayor announced a temporary measure to address local concerns:

"We were tempted and we were asked to install a curfew for a long time. But we resisted because we considered it inhuman and incorrect and counterproductive, but there was a period where tensions were at their peak between the local communities in some neighbourhoods and some ... parts of ... the foreigners in Bourj Hammoud." $\underline{66}$

His justifications highlight the pressure he faced from the Internal Security Forces, the muhafaza of Metn 67 and the residents. The curfew was presented as the only solution given the lack of resources and the limited responsibilities of the municipal police, and the specificities of the urban fabric in Bourj Hammoud: "There are so many narrow streets, you could miss an incident happening a few meters away, it would require to have 10 times more policemen working on constant shifts." 68 During the interviews conducted in January 2015, the Bourj Hammoud officials assured that the curfew had been enforced only during two weeks over the summer: "It was a way to calm down the society, a little. To tranquilise. But now it is over." 69 The announcement of the curfew was clearly a sign sent to local residents: an instrument of communication.

Nonetheless, according to many informants, the curfew was still implemented as of May 2015. Syrian manual workers and local residents mentioned the "curfew that forced [them] to come back home before 6 pm." Over the course of the research, I was systematically asking Syrian residents and refugees if they were living under curfew. I obtained many responses from informants: "Yes," "No," "It depends," "I don't know". These inconsistencies might stem from the fact that informal militias are 
also regulating the outdoor space. As the municipal police of Bourj Hammoud had integrated in its ranks the ex-members of the Armenian militia after the Civil War, the boundaries are sometimes blurred between official and informal policing. Rana, resident of the predominantly Shi'a neighbourhood of Naba'a, explains that the fehood [a local figure] started to guard the neighbourhood along with the police: "They started daily patrols because the neighbourhood lacked safety and so the troubles have decreased now, now there are none." 70 The municipal officials never mentioned directly the link between the municipality and these militias and prefer mentioning their will to nicely negotiate with the trouble-makers. As one of the officials recalls to me:

"We talked very nicely, very politely. Very calmly; and we made [some Syrian refugees] understand that we will not tolerate such behaviour [he refers to the episode that triggered the curfew] and if you want to live here, to make a living... you should not bother anyone. [...] When some of them failed to understand the message, we made it very clear in other ways... so they got the message and calmed down." 71

Thus, the implementation of the curfew reveals the ambiguity in policing outdoor space, not necessarily policed by the official security forces and not monitored at all times. With this, not all Syrians abide curfew. According to one Syrian manual worker in Bourj Hammoud:

"Yes, well... I can't be at home after 8 until next day. It is too small. I live in a room with 16 men. No kitchen, no toilet. I cannot stay inside all the time. So ... the rule is more or less followed."72

The enforcement of the curfew in Bourj Hammoud follows a flexible pattern. It contrasts with the practices of the neighbouring municipalities and the strict guidelines they impose in order to regulate activities and people operating in the space. When the first Syrian refugees arrived, the few public spaces in inner-Beirut which had been under the constant surveillance of security agents since the reconstruction73 became more regulated. At the beginning of the summer of 2014, the garden of Sanayeh, centrally located in Beirut, opened after years of renovation. Local residents reported their fear of seeing Syrians use the park: "They are opening the park now... Imagine there are a lot of Syrians, they will come and destroy it." 74 At the entrance of the park, a large board warns the users about the requested behavior inside the park (smoking is forbidden, picnicking is forbidden, playing football is forbidden). Visitors are notified that if they do not abide by the rules, they will be evicted from the garden. The garden is "normalized" 75 to exclude the undesirable. Even in Bourj Hammoud, the arrival of refugees has led to stricter regulations of the municipal public garden. The municipality, witnessing a rapid increase in the number of users of the park, located under the elevated highway (Yerevan Bridge), and fearing for their security, posted municipal agents at the entrance. Yet, these agents, sitting on plastic chairs next to the entrance of the park, let in all Syrian families and children who wish to enter. 
In Bourj Hammoud, because of the loose imposition of the curfew and the absence of fancy malls, bars and expensive restaurants and their associated security guards, the urban poor are able to be in public spaces without as many restrictions as in other areas of Beirut. The open spaces are not policed like in downtown Beirut or in Sin el-Fil. Municipal officials, who sometimes regret this discrepancy, have noticed this lack of control:

"In Bourj Hammoud, the behaviour in the street is different. On the sidewalks, on the streets, the water-pipes. People do what they want with public goods. They take this empty lot to make it a garden or to place trash. It would be better with more consideration. Here, you cannot wait for the policemen to enforce the laws strictly." $\underline{\underline{6}}$

Indeed, the residents of Bourj Hammoud encroach daily on outdoor space through various practices: the shop-keepers use the sidewalks to display their articles for sale; on a few corners, some residents set-up small shrines or arrange a collection of plants in plastic pots to prevent people from littering; some place trays of flowers on the sidewalks to prevent the cars from parking while others use iron bars and lockers to keep their parking spot. Thus, the imposition of a curfew in Bourj Hammoud might have contributed to reducing personal disputes and crime rates during times of high tension, thus reassuring the local community: "It did lower technically. Because most of the incidents were happening at night, so it lowers the troubles." 77 With this, one cannot overlook the effect of looser refugee practices. The higher degree of informality in Bourj Hammoud does not mean there is an absence of norms. Rather, behaviours are monitored in Bourj Hammoud, and although the modalities of expression of such norms might be more flexible than in downtown. The discontinuities and hybridizations in the regulation of public spaces 78 open voids in which the residents can escape tight municipal requirements. This flexible regulation of the refugees in Bourj Hammoud allows refugees to become urban dwellers: In the face of aid-providers and policemen, refugees may develop strategies and use the rules to ameliorate their settlement.

\section{The agency of "refugees": becoming ordinary urban dwellers in Bourj Hammoud.}

In order to understand why the refugees' settlement did not lead to any unrest, the agency of the Syrian newcomers has to be considered. Becoming a refugee in the suburbs of Beirut does not happen overnight. They have developed their own sets of tools and know-hows in order to get by. Away from the image of the passive refugee, the route to becoming a refugee in the suburbs of Beirut requires Syrians to accomplish a series of steps and administrative procedures, for example, going to the UNHCR building in the southern suburbs of Beirut, obtaining an appointment, and keeping updated the series of forms and registration cards. This article argues that the social stability in Bourj Hammoud can be explained by the fact that the newcomers gradually became capable urban dwellers engaging in ordinary life, becoming more familiar with the neighbourhood and managing to navigate the city safely.

\subsection{Seeking refuge in a city of fantasies and fears: practices of social learning}

Since 2011, Syrians have been seeking refuge in Bourj Hammoud. They arrived with little of their 
belongings and many preconceived ideas of Beirut and Lebanon. Hassan left behind a Syrian regime supporting public university and is now amazed by the neoliberal Lebanon. He was also surprised to see people drinking in the streets and to see some women dressed as they were, comparing them to women he envisioned lived in "Las Vegas."79 Most of the Syrian refugees had never been in Lebanon before their flight and their knowledge about daily life in Lebanon's capital was restricted to pop culture references and the stories told by Syrian acquaintances coming back from Beirut. Yet, gradually, they became familiar with the city. Public spaces, such as commercial streets, public gardens, NGOs' premises, and school courtyards, enabled the refugees to acquire familiarity with their neighbourhood. They learn the codes: "I go to the market around 6 at night. It is cheaper. We get cheaper deals." 80 After a few months or years in the locality, refugees, as any urban dweller, master the art of shopping in their streets. They know where the best spot to buy fresh and cheap vegetables is and where to catch the buses. Haig is an Armenian architect who grew up in Bourj Hammoud. When I met him, he explained to me the difference between the insiders and the outsiders:

"If you are from the neighbourhood, you know somehow what each part of the neighbourhood represents, you know. You move [and orient yourself] based on a lot of landmarks that are around: churches or schools or the political clubs... But to an outsider, it is all the same. The outsider can easily get lost. [In Bourj Hammoud], there is no line [to differentiate] between the mass and the void and no sense of orientation. The density is very high" 81

Gradually, refugees learn to locate landmarks such as the mosque, the bridge, the municipal square, the police station, and the gun shop. They even learn words in English, Armenian, and French as a social worker in the area recalls:

"There were Syrian families that did not know any Arabic, Kurdish families. They wanted to learn Arabic and now, it is incredible! [This lady] she started to talk in Arabic!" $\underline{2}$

This social worker also remarked: "there is no dialogue here, people only look at each other, they sniff each other." 83 This comment was made with a sad tone. Yet, much of the social peace of Bourj Hammoud could be explained by this mutual observation. The following are extracts from a series of conversations I had with an Armenian shop-owner. He sells mattresses and duvets under the Yerevan Bridge. The large street is always very busy. His shop is located right next to a café and this Armenian shop-owner spends most of his time monitoring the street activities:

"These two, I think they are lovers. They are like birds. [Syrian workers] are there, at this café, all the time. They can stay sitting there all day long. For $500 \mathrm{lbp}$, it does not cost them anything. Their houses are really small I think, they have no place to go, so they sit there all day. And they drink coffee. They smoke very cheap cigarettes. Look at these cigarettes. They pay $500 \mathrm{lbp}$ and they stay there 500 hours! They come back from work. I hear them. [...] In this street there are 
many small cafés that open like this. Him, that's an old criminal. He used to be part of the militia. Then he went to jail. These men who sit here, they work in the industrial zone over there. There was a fire today there so it will be 60 more men unemployed." 84

"I don't know why they love sitting under the tree like this. Sometimes I dream that I wake up and that the tree has moved. And so they are not next to my shop anymore. I think they just like the atmosphere under the tree. And god! They smoke all the time. Without stopping. They buy these very cheap packets for 500 LBP. And they play tawla. They smoke. They play. And they stay here and talk for hours. I was listening before. One of them was getting angry because the other one was cheating. And then they make big moves with their arms. Like this." $\underline{55}$

"Look at him! Him, he is Syrian Armenian. I know him a bit now. He is a hairdresser. A good hairdresser, I know him now. We can talk and he will give you a good price." $\underline{86}$

By looking at each other, urban dwellers of Bourj Hammoud, either long-term residents or Syrian refugees, practice what E. Anderson called "folk ethnography," in which outside, public places encourage learning from the "other" by creating spaces for small and repeated interactions. These repeated interactions help make sense of the other. This article argues that the peaceful settlement of refugees in Bourj Hammoud has to do with this process of "up-close observations of others, [which] includes inadvertent eavesdropping and what are in effect informal studies of the local people, creating a mental picture of the nature of the setting and of certain kinds of others." 87 All the residents of Bourj Hammoud perform these moments of observations while noting people and their background, whether the residents are old Armenians or young refugees. Once, a Portuguese housekeeper even told me that she "always listens to people when [she] waits for the bus." The result of such folk ethnography is a smoother cohabitation between the refugees and the residents who are turning the unknown "host" and the undesirable "refugee" into a familiar neighbour.

\subsection{Navigating the unknown city and mastering invisibility in Bourj Hammoud}

Public order, as defined by the sociologist E. Goffman, finds its roots in the immediate interactions of strangers on public spaces and in the way they handle themselves. This paper was also inspired by his fertile hypothesis, which encourages looking at "the regulation of face-to-face interactions among members of a community who are not well acquainted." 88 Each user of the public space masters the distinction between acts that are approved (e.g. crossing the street between two cars) and improper acts (e.g. walking in the middle of the road) that will attract attention. Each user is taken in an information flow. Without engaging in conversation and only through one's physical presence, a passerby receives and conveys embodied information.

Public order is guaranteed when two passersby in "co-presence" 89 grant each other with civil inattention: "one gives to another enough visual notice to demonstrate that one appreciates that the other is present [...] while at the next moment withdrawing one's attention from him so as to express that he does not constitute a target of special curiosity or design." 90 Bashir is a Lebanese painter and 
bartender whose lifestyle is not well regarded by his parents:

"I live in Dora [one of the neighbourhoods of Bourj Hammoud]. There I prefer... it is just that I can feel that... no one is asking me who I am. That's usually one of the first question that people ask you in Lebanon. They ask: where are you from? In Dora there are a lot of different people. So I am better. I feel that I can be myself." $\underline{91}$

When the city is hostile and unknown for the unfamiliar and stigmatized Syrian refugees, the anonymity of the large metropolis becomes a precious asset. In the streets and buses of Bourj Hammoud, the rich variety in the appearance of the people offers anonymity to the individual, hidden in the crowd. 92 Between the group of Ethiopian women, the Sudanese male teenagers and the veiled Shi'a women, the Syrian refugees are not noticeable. They are protected under the "film of anonymity." 93 Without this protective film, the peaceful coexistence of thousands of inhabitants would not be possible. The souq of Bourj Hammoud attracts a wide range of customers from all over the city who want to benefit from the fair prices or to purchase specific ethnic products.94 Many times, the informants said: "Bourj Hammoud, you will find everything here: Sunni, Shi'a, Christian, Lebanese, Syrian, Bangladeshi, Sri Lankan..." This dense and heterogeneous social fabric grants the Syrian refugees with a "protective envelope of anonymity" 95 that enable them to navigate and acquire the necessary skills to engage in city life. Many times, I asked policemen how they recognize Syrians in the streets from afar:

"I look around if there is something wrong. If something looks weird, I walk across the neighbourhood and I look at everyone's appearance, if something is happening. Maybe a Syrian... [...] Everything that looks weird. I go and I see. How are the behaviours? I go down the buildings. I know what I am doing."96

Syrian refugees in Bourj Hammoud, due to repeated use of public space and social learning, are able to "behave properly." 97 They know how not to attract undue attention and keep "within the spirit or ethos of the situation" in order not to be "de trop or out of space."98 A Syrian worker who has been working on and off in Bourj Hammoud for over ten years, once told me: "The Syrian change colour, they have to. They have to [camouflage themselves] so that they can survive."99 In Syx Street, in Naba'a, Syrians have opened most of the clothes shops over the last two years. When I am walking around with Khadije, a Lebanese Shi'a, she tells me: "Look, this is the last Lebanese grocery shop of the street." 100 She makes her observations with a neutral voice and no hostility. These are facts that have become ordinary: "They are all Syrian. This shop, this shop, this shop. Syrian. Syrian, Syrian. All of that is now Syrian. In this building, it is only Syrian now." Undeniably, because she lives in the neighbourhood, she can identify the buildings and knows the stories behind the shops. Yet, when looking at the traffic of people in the street, she admits that she is unable to distinguish between the Lebanese and the Syrian passers-bys. 
In Bourj Hammoud, Syrian refugees reconnect with ordinary life and acquire familiarity with their new neighbourhood because of the public spaces available to them. They participate in folk ethnography with their fellow residents and learn from and about each other. This contributes to easing tension in relationships between very diverse population groups. Syrian refugees in Bourj Hammoud are granted civil inattention and thus taken into the flow of peaceful social intercourses. They master the art of navigating city streets, protected by a relative anonymity.

\section{Conclusion}

As underlined a year ago in the introduction to the Civil Society Review by its editors, "it is unprecedented to have a country of 4 million inhabitants host one million refugee without being on the verge of a social rupture or a war." 101 How do Syrian refugees and host communities manage to live side by side, communicate and cooperate despite demographic pressure, past trauma, old grievances and the current distress? This paper used the area of Bourj Hammoud as a case study to suggest a multi-fold explanation. It pointed at the dynamism of the local communities, Bourj Hammoud's residents' specific religious or historical ties with Syrian refugees, lenient municipal regulation of refugees movement, and the abilities of the refugees to navigate the city. Can this specific case of peaceful coexistence inform conflict-solving specialists and policy makers interested in social stability? Undeniably, the specificities of the locality of Bourj Hammoud should not be overlooked. Nonetheless, this zoom-in into the suburbs of Beirut reasserts the need to study the entanglement of the microstrategies of residents, and of refugees, with local and national public policies.

\section{Bibliography}

Elijah Anderson, "The Cosmopolitan Canopy", Annals of the American Academy of Political and Social Science, Vol. 595, Sep 2004, pp. 14-31.

John Chalcraft, The invisible cage, Syrian migrant workers in Lebanon, Stanford University Press, Stanford, California, 2009.

Assaf Dahdah, "Beyrouth, entre cosmopolitismes et coexistences", in "L'art du faible » : Les migrantes non arabes dans le Grand Beyrouth, Beirut, Presses de l'Ifpo, 2012.

Erving Goffman, Behavior in Public Places, The Free Press, New York, 1963.

Suad Joseph, The politicization of religious sects in Burj-Hammoud, Lebanon, Colombia University, PhD dissertation, 1975.

Colette Petonnet, «L'anonymat ou la pellicule protectrice », Le Temps de la réflexion VII (La ville inquiète), Paris, Gallimard, 1987.

Liisa Malkki, "National Geographic: The Rooting of Peoples and the Territorialization of National Identity among Scholars and Refugees", Cultural Anthropology, Vol. 7, No. 1 "Space, Identity, and the Politics of Difference", Feb 1992, pp. 24-44. 
Loïc Wacquant, "Scrutinizing the Street: Poverty, Morality and the Pitfalls of Urban

Ethnography”, American Journal of Sociology. Vol.107, n6. May 2002, pp. 1468-1532.

- 1. This article is based on the research I conducted for my master thesis in urban policies and sociology: "Refugees in a City of Conflicts, Settlement of Syrian Refugees in Beirut \& the Accomplishment of Everyday Life" (under the supervision of Adrian Favell \& defended in front of the Jury of The Doctoral School of Sciences Po in June 2015).

- 2. All the names of the respondents have been anonymized.

- 3. The official number of Syrian refugees registered in Lebanon by the UNHCR reached 1,069,111 in December 2015. See: UNHCR, online data portal, http://data.unhcr.org/syrianrefugees/country.php?id=122 [last accessed 28 January 2016]. Yet, the Lebanese Crisis Response Plan 2016 - 2017 estimates that there are 1.5 million "displaced Syrian living in Lebanon." See: Government of Lebanon \& United Nations, Lebanese Crisis Response Plan 2016-2017, 15 December 2015, 144p.

- 4. UNHCR, Syria Regional Response Plan (RRP5), December 2012, p.33.

- 5. Mona Alami, "Averting a Crisis: Syrian Refugees in Lebanon", Carnegie Middle East Centre, May 28, 2013, available at: http://carnegie-mec.org/2013/05/28/averting-crisis-syrian-refugeesin-lebanon [last accessed 28 January 2016].

- $\underline{6}$. The arrival of refugees has also raised "older" issues of contention, such as the status of Palestinian refugees in Lebanon, In December 2012, the Lebanese Minister of Energy, Gibran Bassil, declared that the borders should be closed to the Syrian refugees because: "It is enough! We have already the Palestinians in Lebanon" See: "el-wazir Bassil Gibran leyssa a'nsuria", Al-Akhbar, Arabic, 24 December 2012, http://www.al-akhbar.com/node/174259 [last accessed 28 January 2016].

- 7. Beirut Research and Innovation Center \& the Lebanese Center for Studies and Research, Citizen's perceptions of security threats stemming from the Syrian refugee presence in Lebanon, International Alert, February 2015.

- 8. Aristide R. Zolberg, Astri Suhrke, and Sergio Aguayo, Escape from violence: Conflict and the refugee crisis in the developing world, New York: Oxford University Press, 1989. Gilbert Damian Loescher and James Milner, Protracted refugee situations, Abingdon, New York: Routledge for the International Institute of Strategic Studies, 2005.

- 9. Lebanese and foreign press published articles on this issue, on weekly basis between 2012 and 2014. For instance: Samer El-Hosseini "a'adad el-naazeheen el-suriyin tatajawaz qudarat el-Beqaa a'la istiabihum", As-Safir, Arabic, 31 July 2012, http://assafir.com/Article/283014 [last accessed 28 January 2016]. "Syrian Refugee Tents torched in Bekaa over Alleged Rape", Naharnet, English, 2 December 2013 http://www.naharnet.com/stories/en/108174 [last accessed 28 January 2016]. Carine Torbey, "Syrian refugees in Lebanon fuel tensions", BBC News, English, 9 April 2013, http://www.bbc.com/news/world-middleeast-22029136[last accessed 28 January 2016]. "Tensions between Syrian refugees and Lebanese Shiites", Yalibnan, English, December 7, 2013, http://yalibnan.com/2013/12/07/tension-between-syrian-refugees-and-lebanese-shiites/ [last accessed 28 January 2016]. Kareem Shaheen, "Syria-linked clashes in Beirut leave one dead", The Daily Star, English, 24 March 2014, http://www.dailystar.com.lb/News/LebanonNews/2014/Mar-24/251161-syria-linked-clashes-in-beirut-leave-one-dead.ashx 
[last accessed 28 January 2016].

- 10. See: Human Right Watch Lebanon, Rising Violence Targets Syrian Refugees, 30 September 2014.Levant7, Drivers of Instability, Conflict and Radicalization, A snapshot from Akkar, January 2015. World Vision International, Under Pressure, The Impact of the Syrian Refugee Crisis on host communities in Lebanon, July 2013. Search for Common Ground, Dialogue and Local Response Mechanisms to Conflict Between Host Communities And Syrian Refugees in Lebanon, November 2013. Charles Harb \& Rim Saab, Social Cohesion and Intergroup Relations: Syrian Refugees and Lebanese Nationals in the Bekaa and Akkar, Save the Children \& The American University of Beirut, May 2014.UNHCR, Women Alone. The fight for survival by Syria's refugee women, July 2014.

- 11. Lebanon Support, The conflict context in Beirut: the social question, mobilisations cycles, and the city's securitization, Conflict Analysis Report, 2015.

- 12. UNHCR registration data and estimates are available on the online data portal, op. cit.

- 13. Mona Fawaz, "Neoliberal Urbanity and the Right to the City: A View from Beirut's Periphery", Development and Change, n40, Issue 5, September 2009, pp. 827-852. Eric Verdeil, "Reconstructions manquées à Beyrouth. La poursuite de la guerre par le projet urbain", Les Annales de la Recherche Urbaine, vol 91, 2001, pp. 65-73.

- 14. Mona Fawaz, M. Harb and A. Gharbieh, "Living Beirut's Security Zones: An investigation of the Modalities and Practices of Urban Security", City \& Society, Vol. 24, Issue 2 2012, pp. 173-195.

- 15. Lebanon Support, Politics of security, discourses of fear and economic fatigue: the conflict dynamics in Matn, Conflict Analysis Digest, August 2015.

- 16. M. Christophersen, C. Thorleifsson, Å Tiltnes, Ambivalent Hospitality. Coping Strategies and Local Responses to Syrian Refugees in Lebanon. Fafo AIS, 2013.

- 17. Officially, 19,477 refugees indicated "Bourj Hammoud" as their place of residence when registering with the UNHCR, as for March 2015. The figures do not account for the refugees who change their place of residence after registration (the one who left Bourj Hammoud or moved in) and for the Syrian who decided not to register as refugees.

- 18. UNHCR, Cadastral Areas Ranked by Vulnerability [Excel file], 30 January 2014.

- 19. Interview by the author with vice mayor of Bourj-Hammoud, February 2015.

- 20. Suad Joseph, The politicization of religious sects in Burj-Hammoud, Lebanon, Colombia University, PhD dissertation, 1975.

- 21. UNHCR and UNICEF, Reaching the 225 Most Vulnerable Localities in Lebanon, October 2013.

- 22. See for instance: World Bank, "Local authorities taking account of the major urban risks, the example of the City of Bourj Hammoud, Lebanon", Nov. 2005, World Bank Publications.

- 23. "Calls to evict Kurds after Bourj Hammoud altercation", Now Media, English, 18 May 2014, https://now.mmedia.me/lb/en/archive/547813-calls-to-evict-kurds-after-bourj-hammoudaltercation [last accessed 29 January 2016]. "Five Syrians involved in Bourj Hammoud clash arrested" National News Agency, English, 18 May 2014, http://www.nna-leb.gov.lb/en/shownews/26952/nna-leb.gov.lb/en [last accessed 29 January 2016]. "Affrontements arméno-kurdes à Bourj Hammoud (Liban)", Turquie News, English, 26 May 2014 http://www.turquienews.com/revue-de-presse/sur-la-toile/22254-affrontements-armeno-kurdes-a.html [last accessed 29 January 2016].

- 24. Interview by the author with resident, March 2015. 
- 25. Erving Goffman, Behavior in Public Places, The Free Press, New York, 1963, p.4.

- 26. Ibid.

- 27. See: Liisa Malkki, "National Geographic: The Rooting of Peoples and the Territorialization of National Identity among Scholars and Refugees", Cultural Anthropology, Vol. 7, No. 1 "Space, Identity, and the Politics of Difference", Feb 1992, pp. 24-44. Michel Agier, "Between war and city: towards an urban anthropology of refugee camps", Ethnography, Vol.3 (3) 2002, pp. 317-341.

- 28. As regards the role of critical theory in ethnography and the production of new theories, I followed the approach of the concurrent school of Global Ethnography, developed by Michael Burawoy who does not see in "the case study [...] a potential exemplar of some general law or principles that apply across space and time" (Ethnography unbound. Power and resistance in the modern metropolis, University of California Press, Berkeley, 1991, p.8). Instead, the "Extended Case Method" (The Extended Case Method", Sociological Theory, Vol.16, No.1, March 1998, pp. 4-33), stems from the belief that the micro reality is shaped by the external forces of the macro-world, which in turn is shaped and conditioned by the micro-world. The Global Ethnographer does not look for a common pattern among diverse cases, but s/he highlights the sources of the differences between the local situations. The external forces, which structure (and are structured by) the everyday world, connect each case. Thus, the social phenomena do not lead to the discovery of new theory emerging from the field. Consequently, I explore the risk and potential benefits in weaving together adverse schools, following William Julius Wilson's observation that theoretical insights are neither strictly deductive nor inductive, but represent a combination of both (William J. Wilson and Anmol Chaddha, "The role of theory in ethnographic research". Ethnography, 10 (4) 2009, pp.549-564).

- 29. Georg Simmel, Sociologie. Études sur les formes de la socialisation, Paris, PUF 1999, 1908. Jane Jacobs, The death and life of great American cities. New York: Random House, 1961. Don Mitchell, "The End of Public Space? People's Park, Definitions of the Public, and Democracy", Annals of the Association of American Geographers, 85(1), 1995, pp. 108-133. Richard Sennet, "Reflections on the public realm", in G. Bridge and S. Watson (Eds), The City, Blackwell, Oxford. 2003. Colette Petonnet, «L'anonymat ou la pellicule protectrice », Le Temps de la réflexion VII (La ville inquiète), Paris, Gallimard, 1987. Elijah Anderson, "The Cosmopolitan Canopy", Annals of the American Academy of Political and Social Science, Vol. 595, Sep 2004, pp. 14-31.

- $\underline{30 .}$ The very choice of the case study and the framing of the research question were influenced by the researcher's implicit beliefs. Given the desperate situation experienced by countless Syrian families, asking the question of "what did work?" may sound at worse provocative or at best naïve. I acknowledge the deforming lens through which European educated scholars could be tempted to look at the current stakes. At a moment where the dominant discourse in Europe claims that the maximum number of migrants that European cities, economies or health systems can absorb has been reached, the Lebanese case is rich in lessons. A great influence of my work was Loïc Wacquant's analyses and notably his critical essay "Scrutinizing the Street: Poverty, Morality and the Pitfalls of Urban Ethnography" (American Journal of Sociology, Vol.107, n6. May 2002, pp.1468-1532), which identify the major dangers when sociologists looked at "dishonoured social figures": the "moral schemata and expectations of the audience" and "the dangerous suspension of analytic judgement" (Ibid, p.1470). While trying to counter common sense, I tried to not develop a romanticized view on the topic and replace the 
stereotypes about the figure of the Syrian refugee or the violence of urban life by other idealistic portrayals "issued out of the same symbolic frame" (Ibid).

- 31. Mona Fawaz \& Isabelle Peillen, "The case of Beirut, Lebanon", in Understanding slums: Case studies for the Global Report in Human Settlements, 41p. 2003.

- 32. Joseph, 1975, op. cit.

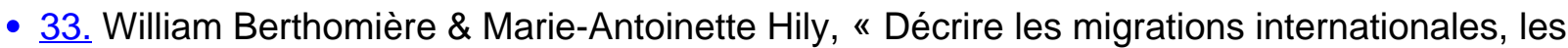
expériences de la coprésence », p.67-82, Revue Européenne des migrations internationales, vol. 22-n², 2006.

- 34. Interview by the author with a shopkeeper, March 2015.

- 35. Interview by the author with a social worker, February 2015.

- $\underline{36}$. During the civil war (1975-1990), the fortified urban boundaries conditioned many aspects of city life, sociability and mobility patterns. Walls and barricades cutting main roads and blocking enemy infiltrations divided the inhabitants and served as the basis for massacres (see: Jon Calame \& al., Divided Cities Belfast, Beirut, Jerusalem, Mostar, and Nicosia, University of Pennsylvania Press, Philadelphia, 2009). The city was articulated along a North-South line starting at the old harbour and the Martyrs' place following the Damascus road. The high level of random violence led to territorial homogeneity. Beirut residents fled mixed neighbourhoods where their security was not guaranteed and grouped into homogeneous ethnic, political and religious enclaves producing a segregated urban geography (S. Saadeh, "Les conséquences du sectarisme sur l'espace public de Beyrouth", Cahiers de la villa Gillet, Vol 15. November «Villes et Religions », 2001, pp. 67-80).

- 37. Interview by the author with resident, March 2015.

- 38. Interview by the author with a resident, March 2015.

- 39. Interview by the author with International NGO staff, February 2015.

- 40. Interview by the author with vice mayor of Bourj Hammoud, February 2015.

- 41. Mona Fawaz, 2003, op. cit.

- 42. UNHCR and UNICEF, Reaching the 225 Most Vulnerable Localities in Lebanon, map, October 2013, https://data.unhcr.org/syrianrefugees/download.php?id=3775 [last accessed 29 January 2016].

- 43. UNHCR, 3RP Regional Refugee Resilience Plan 2015 - 2016, Regional Strategic Overview, 2014, https://data.unhcr.org/syrianrefugees/download.php?id=7908 [last accessed 29 January 2016].

- 44. UNHCR, 2012, op. cit.

- 45. UNHCR, Lebanese Communities in Focus: Supporting Communities Protecting Refugees, 2014, 116p.

- 46. See: Estella Carpi, "The Everyday Experience of Humanitarianism in Akkar Villages", Civil Society Knowledge Center, Lebanon Support, 2014.

- 47. Interview by the author with International NGO Deputy Director, February 2015 and informal talks with UN staff members.

- 48. Interview by the author with International NGO Deputy Director, February 2015.

- 49. Political parties play significant role in providing social services to the residents or policing the streets. The Tashnak, one of the few Armenian parties, is very well established in BurjHammoud (with the notable exception of the streets of Naba'a, controlled by Hezbollah).

- 50. Interview by the author with a social worker, February 2015.

- $\underline{51 .}$ These beliefs spread even though the Syrian workers did not come from a supposedly 
remote and primitive Syrian countryside, cut from the "institutions and forces of capitalist modernity." Their subordinate position in the Lebanese labor hierarchy cannot be explained by their so-called "traditional culture of backwardness and rural stupidity". Instead, as shown by Abu Lughod and later by Chalcraft, the Syrian workers were already involved in their home county in the world power system of capitalist production. Thus, their migration stems from the need to renovate and restore their access to viable means of production and domestic community. See: Janet Abu Lughod, "Recent Migrations in the Arab World", in Arab Society : Social Science Perspectives, edited by Saad Eddin Ibrahim and Nicholas S. Hopkins (Cairo: American University in Cairo Press, 1985), pp.177-188.John Chalcraft, The invisible cage, Syrian migrant workers in Lebanon, Stanford University Press, Stanford, California, 2009.

- $\underline{52 .}$ Hussein Hazuri, "el-tawsia' el suria gheer hawytaha...el-hamra ma a'adet lubnania”, Al-Nahar, Arabic, 6 January 2015, http://newspaper.annahar.com/article/203070 [last accessed 29 January 2016].

- 53. Chalcraft, 2009, op. cit.

- 54. Tristan Khayat, "Borj-Hammoud, de l'espace communautaire à l'espace public croissance d'un quartier commercial ", Les Cahiers du Cermoc, "Reconstructions \& Réconciliations au Liban, Négociations, lieux publics et renouement du lien social », 1999, pp.175-186. Tristan Khayat, "La rue, espace réservé : voituriers et vigiles dans les nouvelles zones de loisirs à Beyrouth ", Geocarrefour, Revue de Géographie de Lyon, "Espace public au Moyen-Orient et dans le monde arabe, Entre urbanisme et pratiques citadines », Vol. 77 (3), 2002, pp.283-288 Assaf Dahdah, «Beyrouth, entre cosmopolitismes et coexistences », Ch.4, in : « L'art du faible » : Les migrantes non arabes dans le Grand Beyrouth, Beirut, Presses de l'Ifpo, 2012.

- 55. See: Chalcraft, 2009, op. cit.

- 56. Interview by the author with a social worker, February 2015.

- 57. Interview by the author with a resident, January 2015.

- 58. Interview by the author with an urban planner, February 2015.

- 59. The Armenian Revolutionary Federation, known as "Tashnak" is an Armenian nationalist and socialist political partyfounded in 1890. Its headquarters are located in Bourj Hammoud from where it dominated the Armenian political scene.

- 60. See Suad Joseph in 1975, op. cit.

- 61. Wacquant, 2002, op. cit. p. 1524.

- $\underline{62}$. At the national level, the decision of the authorities not to open refugee camps should not be mistaken for the will to integrate them into the Lebanese society. If the Lebanon Roadmap of October 2013 mentioned the need for more "social cohesion" between the refugees and the local communities, the response quickly shifted towards a harsher control on the newcomers. In September 2014, "social cohesion" does not appear anywhere on the official roadmaps, which now mention "social stability". Publicly, the Lebanese government condemns the curfews. Yet, "in order to ensure minimum levels of stability" the government announced that they would "strengthen the capacity of the Lebanese Armed Forces" (Lebanon Crisis Response Plan, 2014, p.14).

- 63. Maya el-Helou, "Refugees Under Curfew: The War of Lebanese Municipalities Against the Poor”, Legal Agenda, English, 22 December 2014, $<$ http://english.legal-agenda.com/article.php?id=674\&lang=en $>$ [last accessed 29 January 2016]. 
- 64. As defined by Goffman. See: Goffman, 1963, op. cit. p.10.

- 65. Interview by the author with a member of the municipal police in March 2015.

- 66. Interview by the author with the vice mayor of Bourj Hammoud, February 2015.

- 67. Bourj Hammoud administratively is part of the governorate of Metn, in the region of Mount Lebanon.

- $\underline{68}$. Interview by the author with the vice mayor of Bourj Hammoud, February 2015.

- 69. Ibid.

- $\underline{70 .}$ Interview by the author with a resident of the neighbourhood of Naba'a (Bourj Hammoud), March 2015.

- 71. Interview by the author with a municipal official, February 2015.

- $\underline{72 .}$ Interview by the author with a Syrian worker, March 2015.

- 73. Liliane Barakat and Henri Chamussy, "Les espaces publics à Beyrouth », Geocarrefour, Revue de Géographie de Lyon, «Espace public au Moyen-Orient et dans le monde arabe, Entre urbanisme et pratiques citadines ", Volume 77(3), 2002, pp. 275-281. Mona Fawaz, 2012, op. cit.

- $\underline{74}$. Interview by the author with a resident of Sanayeh, August 2014.

- 75. Don Mitchell, 1995, op. cit.

- 76 . Interview by the author with a municipal official, January 2015.

- 77. Interview by the author with municipal agents, March 2015.

- 78. Le Gallès theorized urban governance and policing as discontinuous and nonlinear processes (in time and space), see: Patrick Le Galès, Urban Governance in Europe: What Is Governed?, in Bridge G. and Watson S. (eds), The New Blackwell Companion to the City. Oxford: Blackwell, 2011.

- 79. Interview by the author with a Syrian refugee, March 2015.

- 80. Ibid.

- 11 . Interview by the author with an Armenian architect, February 2015.

- 82 . Interview by the author with a social worker, January 2015.

- 83. Ibid.

- 84 . Interview by the author with a shop owner, February 2015.

- 85. Ibid.

- 86. Ibid.

- 87. Anderson, 2004, op.cit. p.22-25.

- 88. Goffman, 1963, op. cit. p.9.

- 89. Meaning that they both acknowledge the presence of the other.

- 90. Goffman, 1963, op. cit. p.84.

- 91 . Interview by the author with Lebanese resident, June 2014.

- 92. Dahdah on women migrants in Beirut, 2012, op. cit.

- 93. Petonnet, 1987, op. cit. p.247.

- 94. Arpiné Mangassarian, "Bourj Hammoud : logiques municipales entre aménagement, développement et identité patrimoniale » In: Des banlieues à la ville : Espaces et acteurs de la négociation urbaine, Beyrouth, Presses de l'Ifpo, 2013.

- 95. Petonnet, 1987, op. cit. p.247.

- 96. Interview by the author with a policeman, March 2015.

- 97. Goffman, 1963, op. cit. p.11.

- 98. Ibid. 
- 99. Interview by the author with a Syrian worker, March 2015.

- 100. Conversation between the author and a resident, March 2015.

- 101. Lebanon Support, "Revisiting Inequalities in Lebanon: the case of the "Syrian refugee crisis" and gender dynamics", Civil Society Review, 1, January 2015, p.8 